\title{
Correction to: The chemodiversity of paddy soil dissolved organic matter correlates with microbial community at continental scales
}

Hong-Yi Li ${ }^{1}$, Hang Wang ${ }^{2}$, Hai-Tao Wang ${ }^{3,4}$, Pei-Yong Xin ${ }^{5}$, Xin-Hua Xu' ${ }^{1}$, Yun Ma ${ }^{6}$, Wei-Ping Liu', Chang-Yun Teng 1,7, Cheng-Liang Jiang 1,7, Li-Ping Lou' ${ }^{1}$, Wyatt Arnold ${ }^{3,4}$, Lauren Cralle ${ }^{3,4}$, Yong-Guan Zhu ${ }^{8}$, Jin-Fang Chu ${ }^{5}$, Jack A. Gilbert ${ }^{3,4^{*}}$ and Zhi-Jian Zhang ${ }^{1,7,9^{*}}$

Correction to: Microbiome 6, 187 (2018) https://doi.org/10.1186/s40168-018-0561-x

Following publication of the original article [1], the authors identified an error in the name of the third author.

The incorrect author name is: Hai-Tiao Wang

The correct author name is: Hai-Tao Wang

The author group has been updated above and the original article [1] has been corrected.

\section{Author details}

'College of Environment and Natural Resource Sciences, Zhejiang University, 866 Yuhangtang Ave, Hangzhou 310058, China. ${ }^{2}$ National Plateau Wetlands Research Center, Southwest Forestry University, 300 Bailongsi, Kunming 650224, China. ${ }^{3}$ The Microbiome Center, Biosciences Division, Argonne National Laboratory, Lemont, IL 60439, USA. ${ }^{4}$ Department of Surgery, University of Chicago, 5640 South Ellis Avenue, Chicago, IL 60637, USA. ${ }^{5}$ National Center of Plant Gene Research (Beijing), Institute of Genetics and Developmental Biology, Chinese Academy of Sciences, West Beichen Road, Chaoyang District, Beijing 100101, China. ${ }^{6}$ College of Biological and Environmental Engineering, Zhejiang University of Technology, 18 Chaowang Ave, Hangzhou 310014, China. 'Hangzhou Gusheng Agricultural Technology Company Limited, Chongxian Innovation Industrial Park, Chongxian Ave, Hangzhou 311108, China. ${ }^{8}$ Key Lab of Urban Environment and Health, Institute of Urban Environment, Chinese Academy of Sciences, 1799 Jimei
Ave, Xiamen 361021, China. ${ }^{9}$ China Academy of West Region Development, Zhejiang University, 866 Yuhangtang Ave, Hangzhou 310058, China.

Published online: 28 November 2020

\section{Reference}

1. Li HY, Wang H, Wang HT, et al. The chemodiversity of paddy soil dissolved organic matter correlates with microbial community at continental scales. Microbiome. 2018;6:187. https://doi.org/10.1186/s40168-018-0561-X.

The original article can be found online at https://doi.org/10.1186/s40168018-0561-x.

*Correspondence: gilbertjack@uchicgao.edu; gilbertjack@gmail.com; zzhangzhijian@zju.edu.cn

${ }^{3}$ The Microbiome Center, Biosciences Division, Argonne National Laboratory, Lemont, IL 60439, USA

${ }^{1}$ College of Environment and Natural Resource Sciences, Zhejiang University, 866 Yuhangtang Ave, Hangzhou 310058, China

Full list of author information is available at the end of the article

C The Author(s). 2020 Open Access This article is licensed under a Creative Commons Attribution 4.0 International License, which permits use, sharing, adaptation, distribution and reproduction in any medium or format, as long as you give appropriate credit to the original author(s) and the source, provide a link to the Creative Commons licence, and indicate if changes were made. The images or other third party material in this article are included in the article's Creative Commons licence, unless indicated otherwise in a credit line to the material. If material is not included in the article's Creative Commons licence and your intended use is not permitted by statutory regulation or exceeds the permitted use, you will need to obtain permission directly from the copyright holder. To view a copy of this licence, visit http://creativecommons.org/licenses/by/4.0/. The Creative Commons Public Domain Dedication waiver (http://creativecommons.org/publicdomain/zero/1.0/) applies to the data made available in this article, unless otherwise stated in a credit line to the data. 